\title{
EFEKTIVITAS PROGRAM KELUARGA HARAPAN DALAM UPAYA PENGENTASAN KEMISIKINAN DI KECAMATAN LEMBANG KABUPATEN BANDUNG BARAT
}

\author{
Fitri Irvanasari ${ }^{1}$ \\ 1Jurusan Ilmu Pemerintahan, Fakultas Ilmu Sosial dan Ilmu Politik, \\ Universitas Jenderal Achmad Yani, Indonesia
}

\begin{abstract}
Abstrak
Judul penelitian "Efektivitas Program Keluarga Harapan dalam Upaya Pengentasan Kemiskinan di Kecamatan Lembang Kabupaten Bandung Barat". Masalah dalam penelitian belum efektifnya Program Keluarga Harapan (PKH) di Kecamatan Lembang. Dalam penelitian ini, menggunakan metode deskriptif dengan pendekatan kualitatif. Teknik pengumpulan data melalui studi kepustakaan, wawancara dengan informan dan penggunaan dokumen. Adapun informan berjumlah 6 orang, informan kunci dalam penelitian ini adalah Koordinator Pendamping $\mathrm{PKH}$ Kecamatan Lembang, serta adanya informan pendukung yang terdiri dari Staff UPPKH Kabupaten Bandung Barat, Sekretaris Kecamatan Lembang dan beberapa peserta PKH di Kecamatan Lembang. Berdasarkan hasil penelitian diperoleh bahwa pelaksanaan $\mathrm{PKH}$ telah mampu mengurangi beban pengeluaran masyarakat miskin peserta $\mathrm{PKH}$, serta mampu meningkatkan partisipasi peserta PKH dalam mengakses layanan kesehatan serta pendidikan, namun masih ditemui beberapa hambatan yang menjadikan pelaksanaan PKH kurang optimal, hal ini dibuktikan dengan PKH tidak tepat sasaran sehingga menimbulkan masalah, dana PKH yang tidak sesuai dengan keadaan peserta $\mathrm{PKH}$ serta pendamping $\mathrm{PKH}$, jumlah pendamping yang minim, serta pencairan dana $\mathrm{PKH}$ yang tidak tepat waktu. Upaya yang dilakukan untuk mengatasi hambatan adalah pemutakhiran data, penyesuaian dana $\mathrm{PKH}$, penambahan kuota pendamping, serta penyesuaian waktu penyaluran dana.
\end{abstract}

Kata kunci: Efektivitas, PKH 


\begin{abstract}
The research title is "The Effectiveness of the Hope Family Program in Poverty Control Efforts in Lembang District, West Bandung Regency". The problem in this research is the ineffectiveness of the Family Hope Program (PKH) in Lembang District. In this study, using a descriptive method with a qualitative approach. Teaching techniques through literature study, interviews with informants and use of documents. The key informants in this study were the Lembang PKH Assistance Coordinator, as well as supporting informants consisting of UPPKH staff in West Bandung Regency, the Secretary of Lembang District and several PKH participants in Lembang District. Based on the results of the research that the implementation of $P K H$ has been able to reduce the burden on poor community PKH participants, and is able to increase $P K H$ participant participation in accessing health and education, however, there are still some obstacles that show that PKH implementation is less than optimal, this is evidenced by PKH being right on target causing problems, $P K H$ funds that are not in accordance with the circumstances of $P K H$ participants and PKH facilitators, the minimum number of mentors, and disbursement of PKH funds that are not on time. Efforts to overcome these obstacles include updating data, increasing PKH funds, increasing counterpart quota, and extending the time for distribution of funds.
\end{abstract}

Keywords: Effectiveness, $P K H$

\title{
PENDAHULUAN
}

Kemiskinan merupakan sebuah masalah yang sejak dulu hingga sekarang masih juga belum bisa teratasi baik oleh Pemerintah Pusat maupun Pemerintah Daerah. Kemiskinan seakan menjadi momok yang mengerikan dan terus merongrong keadaan ekonomi masyarakat di Indonesia. Hal ini sudah seharusnya menjadi cerminan bagi pemerintah untuk dapat terus berusaha dan berupaya mengatasi permasalahan tersebut. Banyak hal yang menjadi penyebab kemiskinan, diantanya adalah Sumber Daya Alam (SDA), Sumber Daya Manusia (SDM), Pendidikan, lapangan pekerjaan, dan masih banyak faktor-faktor lain yang menyebabkan timbulnya masalah kemiskinan. Secara teoritis kemiskinan dikatakan sebagai sebuah fenomena sosial yang timbul karena taraf hidup masyarakat sebuah negara masih 
sangat memprihatinkan (rendah), sehingga masyarakat tidak mampu memenuhi kebutuhan hidup yang selayaknya.

Berbagai upaya telah dilakukan oleh pemerintah untuk menanggulangi atau mengatasi masalah kemiskinan, akan tetapi tetap saja permasalahan kemiskinan belum dapat teratasi dan belum memberikan dampak besar, sehingga sampai saat ini tujuan dari pembangunan nasional terkait dengan masalah pemerataan dan peningkatan kesejahteraan masyarakat masih menjadi masalah yang berkepanjangan. Upaya yang telah dilakukan pemerintah diantaranya adalah pelaksanaan programprogram dalam upaya mengentaskan kemiskinan, seperti program Bantuan Operasional Sekolah (BOS), Beras Miskin (RASKIN), Bantuan Langsung Tunai (BLT) dan masih banyak program lainnya yang telah berjalan dalam rangka mengurangi kemiskinan di Indonesia.

Tantangan kemiskinan yang dihadapi Bangsa Indonesia mencakup hampir keseluruhan wilayah disetiap daerah, Pemerintah selaku lembaga yang menjadi penanggungjawab hal ini mencoba untuk menyelesaikan permasalahan kemiskinan dengan mengeluarkan program-program untuk menyelesaikan permasalahan kemiskinan, dan diberikan kepada setiap daerah untuk menjalankan program tersebut. Menurut Badan Pusat Statistik (BPS), kemiskinan didefinisikan sebagai kondisi dimana seseorang hanya dapat memenuhi kebutuhan makanannya kurang dari 2.100 kalori per kapita per hari. Syaifullah (2008:3) menyatakan menyenai kemiskinan:

bahwa kemiskinan tidak berakar pada masalah tunggal. Artinya kemiskinan tidak disebabkan oleh kekeliruan distribusi keadilan oleh sebuah lembaga Negara semata. Akan tetapi, banyak faktor yang melatar belakangi kemiskinan terjadi, yaitu: Pertama kemiskinan kultural 
yaitu kemiskinan yang disebabkan oleh budaya dan mentalitas kemandirian ekonomi yang tidak terbangun di tingkat masyarakat. Kedua kemiskinan struktural adalah kemiskinan yang disebabkan oleh kekaburan penyelenggaraan distribusi keadilan oleh lembaga Negara. Singkatnya, kemiskinan struktural bisa dilihat dari maraknya penyelewengan anggaran Negara untuk kepentingan publik melalui korupsi. Ketiga, kemiskinan natural, yaitu kemiskinan yang diakibatkan oleh kondisi masyarakat tidak mempunyai mengembangkan perdayaan ekonomi masing-masing. Misalnya kecacatan fisik yang diderita seseorang.

PKH adalah program pemberian uang tunai kepada keluarga miskin berdasarkan persyaratan dan ketentuan yang telah ditetapkan dengan melaksanakan kewajibannya. Program semacam ini secara internasional dikenal sebagai program conditional cash transfers (CCT) atau program Bantuan Tunai Bersyarat. Persyaratan tersebut dapat berupa kehadiran di fasilitas pendidikan (misalnya bagi anak usia sekolah), ataupun kehadiran di fasilitas kesehatan (misalnya bagi anak balita, atau bagi ibu hamil).

Tujuan utama dari PKH adalah untuk mengurangi kemiskinan dan meningkatkan kualitas sumber daya manusia terutama pada kelompok masyarakat miskin. Dalam jangka pendek, bantuan ini membantu mengurangi beban pengeluaran RTSM, sedangkan untuk jangka panjang, dengan mensyaratkan keluarga penerima untuk menyekolahkan anaknya, melakukan imunisasi balita, memeriksakan kandungan bagi ibu hamil dan perbaikan gizi diharapkan akan memutus rantai kemiskinan antar generasi. Dengan adanya PKH, diharapkan RTSM penerima bantuan memiliki akses yang lebih baik untuk memanfaatkan pelayana sosial dasar kesehatan, pendidikan, pangan dan gizi, termasuk menghilangkan kesenjangan sosial, ketidakberdayaan dan 
keterasingan sosial yang selama ini melekat pada diri warga miskin.

Sasaran Program PKH adalah Keluagra Miskin (KM) dan yang memiliki komponen kesehatan (Ibu hamil, nifas, balita, anak prasekolah) dan komponen pendidikan (SD sederajat, SMP sederajat, SMA sederajat) atau anak usia 7-21 Tahun yang belum menyelesaikan pendidikan wajib 12 Tahun, penyandang disabilitas berat, dan lanjut usia di atas 70 Tahun. Berdasarkan Basis Data Terpadu, peserta PKH harus terdaftar dan hadir pada fasilitas kesehatan dan pendidikan terdekat Kewajiban peserta PKH di bidang kesehatan meliputi pemeriksaan kandungan bagi ibu hamil, pemberian asupan gizi dan imunisasi serta timbang anak balita dan anak prasekolah. Kewajiban di bidang pendidikan adalah mendaftarkan dan memastikan kehadiran anggota keluarga PKH ke satuan pendidikan sesuai jenjang sekolah dasar dan menengah. Khusus anggota keluarga peserta PKH penyandang disabilitas, kewajibannya disesuaikan dengan kondisi disabilitasnya.

Berdasarkan latar belakang yang telah dipaparkan diatas, maka peneliti melakukan penelitian terhadap "Efektivitas Program Keluarga Harapan dalam upaya Pengentasan Kemiskinan di Kecamatan Lembang Kabupaten Bandung Barat”

\section{METODE PENELITIAN}

Dalam penelitian ini, peneliti menggunakan metode deskriptif dengan pendekatan kualitatif. Metode penelitian kualitatif menurut Moleong (2007:6), adalah:

Penelitian kualiatif adalah penelitian yang bermaksud untuk memahami fenomena tentang apa yang dialami oleh subjek penelitian misalnya perilaku, persepsi, motivasi, 
tindakan da lain-lain secara holistik, dan dengan cara deskripsi dalam bentuk kata-kata dan bahasa pada suatu konteks khusus yang alamiah dan dengan memanfaatkan berbagai metode alamiah.

David Williams (dalam Moleong, 2007:5) mendefinisikan penelitian kualitatif adalah "pengumpulan data pada suatu latar alamiah, dengan menggunakan metode alamiah dan dilakukan oleh orang atau peneliti yang tetarik secara alamiah". Menurut Denzin Lincoln (dalam Moleong 2007:5) penelitian kualitatif adalah: "Penelitian yang menggunakan latar alamiah, dengan maksud menafsirkan fenomen yang terjadi dan dilakukan dengan jalan melibatkan berbagai metode yang ada".

Menurut Sugiyono (2014:305), bahwa "dalam penelitian kualitatif yang menjadi instrumen atau alat penelitian yaitu peneliti itu sendiri. Oleh karena itu peneliti sebagai instrumen juga harus divalidasi seberapa jauh peneliti kualitatif siap melakukan penelitian yang selanjutnya terjun kelapangan". Sebagaimana yang dinyatakan oleh Guba danLincoln (dalam Moleong, 2014:168), mengemukakan bahwa manusia sebagai instrumen penelitian mencakup tiga hal,nyaitu:

1. Ciri-ciri manusia sebagai instrumen

2. Responsif

3. Dapat menyesuaikan diri

4. Menentukan keutuhan

5. Mendasarkan diri atas perluasan pengetahuan

6. Memproses data secepatnya

7. Memanfaatkan kesempatan untuk mengklarifikasi dan mengikhtisari

8. Memanfaatkan kesempatan untuk mencari respon yang tidak lazim

9. Kualitas yang diharapkan

10. Peningkatan kemampuan peneliti sebagai instrumen 
Menurut Nasution (dalam Sugiyono, 2014:307) penelitian sebagai instrumen penelitian serasi untuk penelitian serupa karena memiliki ciri-ciri sebagai berikut:

1. Peneliti sebagai alat peka dan dapat bereaksi terhadap segala stimulus dari lingkungan yang harus diperkirakannya bermakna atau tidak bagi penelitian.

2. Peneliti sebagai alat dapat menyesuaikan diri terhadap semua aspek keadaan dan dapat mengumpulkan aneka ragam data sekaligus.

3. Tiap situasi merupakan keseluruhan, tidak ada suatu instrumen berupa tes atau angket yang dapat menangkap keseluruhan situasi kecuali manusia.

4. Suatu situasi yang melibatkan interaksi manusia, tidak dapat dipahami dengan pengetahuan semata. Untuk memahaminya kita perlu sering merasakannya, menyelaminya berdasarkan pengetahuan kita.

5. Peneliti sebagai instrumen dapat segera menganalisis data yang diperoleh. Ia dapat menafsirkannya, melahirkan hipotesis dengan segera untuk menentukan arah pengamatan, untuk mengetes hipotesis yang timbul seketika.

6. Hanya manusia sebagai instrumen dapat mengambil kesimpulan berdasarkan data yang dikumpulkan pada suatu saat dan menggunakan segera sebagai balikan untuk memperoleh penegasan, perubahan, perbaikan.

7. Dalam penelitian dengan menggunakan tes atau angket yang bersifat kuantitatif yang diutamakan adalah respon yang dapat dikualifikasi agar dapat diolah secara statistik, sedangkan yang menyimpang dari itu tidak dihiraukan.

Dalam penelitian kualitatif untuk menentukan informan peneliti menggunakan teknik pengambilan purposiv sampling. Menurut Nasution, (2003:29) mengemukakan bahwa: "dalam penelitian kualitatif tidak ada yang dinamakan populasi". Dalam penelitian deskriptif dengan paradigma kualitatif pengambilan sampel dilakukan dengan purposive sampling (sampel bertujuan), karena penelitian kualitatif ini menjaring dan membutuhkan banyak-banyaknya informasi dari berbagai pihak 
atau berbagai sumber yang dianggap dapat memberikan data yang dibutuhkan.

Menurut Sugiyono (2014:124): "Dalam penelitian kualitatif, informan dipilih secara purposive sampling. Purposive sampling adalah teknik pengambilan sampling dengan pertimbangan tertentu". Pertimbangan tertentu itu dapat berupa penguasaan informasi, orang yang paling banyak terkena kejadian dan sebagainya. Adapun informan yang dipilih peneliti sebagai pemberi informasi terdiri dari:

\section{Unit Pelaksana PKH Kabupaten Bandung Barat}

2.Koordinator Pendamping PKH

3.Sekretaris Kecamatan Lembang

4.Peserta PKH

Teknik Pengumpulan Data

2) Studi Kepustakaan

Studi kepustakaan merupakan suatu usaha yang dilakukan oleh peneliti dengan mengumpulkan dan membaca buku-buku literatur yang ada hubungannya dengan topik penelitian untuk dijadikan wacana. Studi kepustakaan dilakukan untuk mendasari dukungan proses penelitian dan pengkajiannya dengan cara banyak membaca, membahas dan menelaah isi sejumlah buku, dokumen, makalah, diktat serta referensi yang dianggap relevan dengan topik dan obyek penelitian.

Data yang dihasilkan dari studi kepustakaan ini adalah sumber data sekunder, menurut Sugiyono (2013:137) data 
sekunder adalah: "sumber yang tidak langsung memberikan data kepada pengumpul data, misalnya lewat orang lain atau lewat dokumen".

3) Wawancara

Wawancara digunakan sebagai teknik pengumpulan data apabila peneliti ingin melakukan studi pendahuluan untuk menemukan permasalahan yang harus diteliti dan juga apabila peneliti ingin mengetahui hal-hal dari responden yang lebih mendalam dan jumlah respondennya sedikit/kecil. Teknik pengumpulan data ini mendasarkan diri pada laporan tentang diri sendiri atau self-report, atau setidak-tidaknya pada pengetahuan dan/atau keyakinan pribadi.

Pedoman wawancara digunakan untuk mengingatkan interviewer mengenai aspek-aspek yang harus dibahas, juga menjadi daftar pengecek apakah aspek-aspek relevan tersebut telah dibahas atau ditanyakan. Dengan pedoman demikian interviewer harus memikirkan bagaimana pertanyaan tersebut akan dijabarkan secara kongkrit dalam kalimat tanya, sekalipun menyesuaikan pertanyaan dengan konteks aktual saat wawancara berlangsung.

Menurut Hadi (dalam Sugiyono, 2013:137) mengemukakan bahwa anggapan yang perlu dipegang oleh peneliti dalam menggunakan metode interview dan juga kuesioner (angket) adalah sebagai berikut:

1. Bahwa subyek (responden) adalah orang yan paling tahu tentang dirinya sendiri;

2. Bahwa apa yang nyatakan oleh subyek kepada peneliti adalah benar dan dapat dipercaya; 
3. Bahwa interpretasi subyek tentng pertanyaan-pertanyaan yang diajukan peneliti kepadanya adalah sama dengan apa yang dimaksudkan oleh peneliti;

Data dari hasil interview ini adalah data primer, karena peneliti mendapatkan data langsung dari responden yang dipilih menjadi narasumber dalam pengumpulan data untuk penelitian ini.

\section{c. Penggunaan Dokumen}

Riduwan (2004:105) menyatakan bahwa "dokumentasi adalah ditunjukkan untuk memperoleh data langsung dari tempat penelitian, meliputi buku-buku yang relevan, peraturanperaturan, laporan kegiatan, foto, film dokumenter data yang relevan penelitian". Menurut Guba dan Lincol (dalam Moleong 2007:216) menyatakan bahwa "record adalah setiap pernyataan tertulis yang disusun oleh seseorang atau lembaga untuk keperluan pengujian suatu peristiwa atau penyajian akunting”.

Dalam penelitian ini, peneliti melaksanakan penelitian di Kecamatan Lembang Kabupaten Bandung Barat.

Dalam penelitian ini, kegiatan yang dilakukan selama penelitian adalah sebagai berikut:

1. Studi pustaka dilakukan pada bulan Maret 2017-Agustus 2017

2. Penelitian awal dilakukan pada bulan Maret 2017-Mei 2017

3. Pengajuan judul dilakukan pada bulan April 2017

4. Seminar usulan penelitian dilakukan pada bulan Juni 2017

5. Pengumpulan data dilapangan dilakukan pada bulan Juni 2017Agustus 2017 


\section{HASIL DAN PEMBAHASAN}

A. Ketepatan Penentuan Waktu

Ketepatan penentuan waktu pada hakikatnya merupakan sesuatu yang dapat menentukan keberhasilan dari pelaksanaan suatu program ataupun kegiatan. Penggunaan waktu yang tepat akan menciptakan efektivitas pencapaian tujuan yang telah ditetapkan sebelumnya.

Unsur ketepatan penentuan waktu sangat berpengaruh terhadap efektivitas suatu kegiatan ataupun program, karena merupakan salah satu kriteria dalam menentukan keefektivitasan suatu program yang sedang dilaksanakan. Ketepatan waktu dalam pelaksanaan sebuah program dapat dilihat dari kesesuaian penentuan waktu yang telah ditetapkan dengan pelaksaan program itu sendiri. Jika waktu yang telah ditentukan sebelumnya sesuai dengan palaksanaan program tersebut, maka program tersebut dalam hal ini Program Keluarga Harapan bisa dikatakan efektif.

1) Pemberian Bantuan Tidak Berbelit-belit

Masyarakat penerima manfaat $\mathrm{PKH}$ atau yang sering dikenal dengan sebutan Rumah Tangga Sangat Miskin (RTSM) merupakan golongan masyarakat yang tergolong kedalam kategori keberdayaan yang rendah, serta kemampuan dalam mengakses kebutuhan dasar yang rendah, seperti kebutuhan dasar akan kesehatan dan pendidikan. Dengan kondisi RTSM yang tergolong kedalam kategori keberdayaan yang rendah, bukan berarti RTSM penerima manfaat PKH tidak memiliki potensi untuk dikembangkan. RTSM memiliki kapabilitas dan potensi yang dapat dikembangkan dalam proses pertolongan, bahwa masyarakat/peserta PKH memiliki dan dapat menjangkau, 
memanfaatkan, dan memobilisasi asset dan sumber-sumber yang ada di sekitar.

Secara garis besar, tujuan umum dari PKH adalah mengurangi jumlah masyarakat miskin serta mampu memberikan akses untuk memenuhi kebutuhan dasar masyarakat miskin terhadap kebutuhan akan akses kesehatan dan akses pendidikan. Terkait dengan tingkat pendidikan RTSM yang cukup rendah, sangat berpengaruh terhadap pemahaman mengenai prosedur yang harus diikuti oleh RTSM peserta PKH. Salah satu yang harus dilakukan untuk mengatasi permasalahan tersebut adalah dengan penyederhanaan prosedur program, sehingga para peserta PKH dapat memahami prosedur tersebut, serta memaksimalkan peran pendamping PKH ditiap Desa yang telah ditetapkan untuk memberikan arahan dan penjelasan serta mendampingi para peserta PKH dalam menjalani setiap prosedur pelaksanaan $\mathrm{PKH}$.

Dalam hal ini para pelaksana PKH di tingkat Kecamatan mempunyai peran sangat penting dalam memberikan arahan kepada para peserta PKH agar mereka tidak kesulitan dalam memahami serta menjalankan prosedur pemberian bantuan. Menurut hasil observasi peneliti di Kecamatan Lembang, pada saat pertemuan awal peserta PKH dengan pendamping PKH, telah dilakukan sosialisasi mengenai prosedur penerimaan bantuan serta hal-hal lain yang menyangkut kepesertaan PKH. Hal tersebut dimaksudkan agar peserta $\mathrm{PKH}$ memahami prosedur yang mereka lalui sebagai peserta PKH. Namun, dalam pelaksanaanya seperti yang peneliti ketahui dilapangan bahwa RTSM peserta PKH masih sangat kurang paham terhadap prosedur pemberian bantuan, sehingga pada setiap tahapannya harus selalu diarahkan oleh setiap pendamping. 
Berdasarkan uraian hasil wawancara diatas, peneliti menganalisis bahwa prosedur pemberian bantuan dana PKH di Kecamatan Lembang masih diras berbelit-belit dan membingungkan para peserta $\mathrm{PKH}$, hal ini dikarenakan rendahnya pemahaman peserta PKH terhadap prosedur formal, sehingga dalam pelaksanaannya masih harus melibatkan pendamping agar tidak terjadi kesalahan. Dalam kaitannya dengan ketepatan penentuan waktu, prosedur pelaksanaan PKH masih dirasa berbelit-belit sehingga dalam pelaksanaanya membutuhkan waktu yang cukup lama, karena peserta PKH yang harus di damping oleh pendamping sangat banyak dan tidak sebanding dengan jumlah pendamping yang minim.

2) Pelaksanaan Program Keluarga Harapan (PKH) Sesuai Waktu Yang Telah Di Tetapkan

Dalam pelaksanaan sebuah program tentu kesesuaian waktu sangat diperlukan, ketidak tepatan waktu seringkali di temukan dalam pelaksanaan suatu program. Hal tersebut tentu saja mengakibatkan ketidak efektifan dalam pelaksanaan suatu program. Oleh karena itu, untuk meminimalisir terjadinya ketidak tepatan waktu dalam pelaksanaan PKH diperlukan penyesuaian antara waktu yang telah di tetapkan sebelumnya dengan pelaksanaan PKH di lapangan.

Keberhasilan sebuah program dalam terwujud jika program tersebut terencana, terarah dan terukur. Terencana maksudnya perencanaan disusun berdasarkan dasar-dasar yang jelas meliputi latar belakang kondisi awal sebagai baseline, kondisi yang akan datang yang hendak dicapai, tahapan dan waktu pencapaiannya. Terarah maksudnya kondisi yang akan datang 
yang hendak dicapai dideskripsikan dengan jelas dan menjadi barometer arah atau tujuan yang akan dicapai. Terukur artinya ada penetapan indikator-indikator keberhasilan yang jelas.

Berkurangnya jumlah masyarakat miskin merupakan salah satu harapan dari setiap Bangsa, tetapi bukan hal yang mudah untuk merubah kondisi tersebut. Diperlukan program-program yang sistematis dan dalam jangka waktu yang cukup panjang. Namun, setiap program harus mempunyai batasan waktu dengan capaian-capaian hasil dari setiap program tersebut.

B. Ketepatan Perhitungan Biaya

Dalam pelaksanaan suatu program, ketepatan dalam perhitangan biaya tentu saja sangat diperlukan. Ketepatan perhitungan biaya terhadap suatu program, dalam arti bahwa tidak mengalami kekurangan sampai program itu dapat diselesaikan. Demikian pula sebaliknya tidak mengalami kelebihan pembiayaan sampai program tersebut dapat terselesaikan dengan baik dan hasilnya memuaskan semua pihak yang terlibat pada program tersebut, dalam hal ini pelaksana PKH dan peserta PKH itu sendiri.

1) Dana Yang Diberikan Sesuai Dengan Ketentuan

Peneliti menganalisis bahwa kesesuaian dana yang diterima oleh peserta PKH memang sesuai dengan ketentuan baru dari PKH sendiri. Namun, hal ini dirasa tidak adil karena jumlah anggota keluarga setiap kepala keluarga berbeda, dan mempunyai kebutuhan berbeda pula. Selanjutnya, peneliti menganalisis mengenai kesesuaian dana yang diterima oleh para pendamping PKH tidak sesuai dengan pengeluaran yang harus mereka keluarkan dalam melaksanakan tugas mereka sebagai pendamping PKH. Seharusnya, pemerintah lebih memerhatikan 
pengeluaran para pendamping dalam melaksanakan tugasnya sehingga terjadi kesesuaian antara dana yang mereka terima dengan dana yang harus mereka keluarkan dalam melaksanakan tugas mereka sebagai pendamping

2) Efisiensi Dana Yang Dikeluarkan Oleh Peserta PKH

Peneliti menganalisis bahwa efisiensi dana yang dikeluarkan peserta PKH pada pelaksanaan PKH bisa dikatakan efisien, karena pada tahun-tahun lalu peserta PKH dapat mencairkan dana PKH di Kantor POS yang ada di Kota Cimahi, yang jaraknya $\pm 21 \mathrm{KM}$ dari Kecamatan Lembang, dengan ini peserta PKH harus mengeluarkan dana untuk akomodasi ke tempat pencairan dana $\mathrm{PKH}$, namun dengan adanya peran pendamping yang mengusulkan agar pihak POS yang datang langsung ke Kecamatan Lembang. Hal ini dapat meminimalkan biaya, tenaga serta waktu yang harus peserta PKH keluarkan.

C. Ketepatan Dalam Pengukuran

Peneliti menganalisis bahwa pelaksanaan PKH di Kecamatan Lembang telah sesuai dengan salah satu tujuan PKH, yakni mengurangi beban pengeluaran masyarakat miskin peserta $\mathrm{PKH}$, dan untuk meningkatkan nilai tambah ekonomi peserta $\mathrm{PKH}$, program ini memberikan motivasi bagaimana memanfaatkan potensi yang ada dalam diri peserta PKH sesuai dengan potensi diri mereka masing-masing melalui P2K2. Di dalam P2K2, peserta PKH di berikan pembekalan mengenai pengasuhan anak, pendidikan anak, pengelolaan keuangan, kesehatan ibu dan bayi, pencegahan kekerasan terhadap anak, dan sebagainya.

Peneliti menganalisis bahwa tingkat kepatuhan peserta PKH terhadap kewajibannya sebagai peserta PKH telah hampir 
sesuai target, tetapi masih ada beberapa peserta PKH yang masih belum melaksanakan kewajibannya, hal tersebut terus di pantau oleh pendamping PKH serta di beri penjelasan mengenai sanksisanksi yang akan mereka dapatkan ketika mereka tidak melaksanakan kewajibannya, hal ini dilakukan agar peserta PKH patuh pada kewajibannya sebagai peserta PKH. Namun, sanksi tegas sesuai dengan ketentuan masih belum diberlakukan sebagai bentuk ketegasan pendamping terhadap pelanggaran yang dilakukan oleh peserta $\mathrm{PKH}$, hal ini merupakan salah satu faktor mengapa seringkali terjadi pelanggaran yang dilakukan oleh peserta PKH dan tidak memberikan efek jera bagi peserta PKH yang melanggar kewajibannya.

D. Ketepatan Dalam Menentukan Pilihan

Peneliti menganalisis bahwa metode yang dilakukan pendamping kepada peserta PKH telah dilakukan dengan baik yakni melalui cara pendekatan langsung kepada masyarakat peserta PKH agar mereka melaksanaka kewajibannya peserta $\mathrm{PKH}$, serta memantau potensi-potensi yang ada pada peserta $\mathrm{PKH}$ agar ke depannya mereka dapat memanfaatkan potensi yang mereka miliki sebagai sumber pendapatan dan tidak terus bergantung pada bantuan yang diberikan oleh pemerintah.

\section{KESIMPULAN}

Berdasarkan hasil penelitian dan pembahasan peneliti mengenai Efektivitas Program Keluarga Harapan dalam Upaya Pengentasan Kemiskinan di Kecamatan Lembang Kabupaten Bandung Barat, maka peneliti dapat mengambil kesimpulan bahwa: 
1. Ketepatan penentuan waktu, waktu pemberian dana $\mathrm{PKH}$ yang tidak konsisten terhadap waktu yang telah ditentukan

2. Ketepatan perhitungan biaya, dana yang diterima peserta $\mathrm{PKH}$ tidak sesuai dengan keadaan $\mathrm{PKH}$, serta dana akomodasi yang diterima pendamping tidak sesuai dengan jumlah dana akomodasi yang harus dikeluarkan oleh pendamping $\mathrm{PKH}$

3. Ketepatan dalam pengukuran, $\mathrm{PKH}$ telah mampu mengurangi beban pengeluaran masyarakat miskin

4. Ketepatan dalam menentukan pilihan, Jumlah pendamping $\mathrm{PKH}$ yang tidak sebanding dengan jumlah peserta $\mathrm{PKH}$

Berdasarkan uraian kesimpulan diatas mengenai Efektivitas Program Keluarga Harapan dalam Upaya Pengentasan Kemiskinan di Kecamatan Lembang Kabupaten Bandung Barat, maka peneliti mengajukan saran-saran sebagai berikut:

1. Perlu adanya penyesuaian waktu

2. Perlu adanya penyesuaian biaya

3. Perlu adanya ketegasan sanksi

4. Perlu adanya penambahan kuota pendamping $\mathrm{PKH}$

\section{DAFTAR PUSTAKA}

\section{Buku:}

Moleong, Laxy J. 2007. Metode Penelitian Kualitatif. Bandung: PT. Remaja Rosdakarya. , Laxy J. 2014. Metode Penelitian Kualitatif. Bandung: PT. Remaja Rosdakarya. 
Nasution. 2003. Metode Penelitian Naturalistik Kualitatif. Bandung: Tarsito

Nazir, Moh. 2005. Metode Penelitian. Jakarta: Ghalia Indonesia.

Parsudi, Suparlan. 2004. Kemiskinan Di Perkotaan. Jakarta: Sinar Harapan.

Rustanto, Bambang. 2015. Menangani Kemiskinan. Bandung: Remaja Rosdakarya.

Sugiyono. 2013. Metode Penelitian Kuantitatif, Kualitatif dan $R \& D$. Bandung:

Alfabeta.

. 2014. Metode Penelitian Kombinasi. Bandung: Alfabeta.

Supriyono.2000. Sistem Pengendalian Manajemen. Yogyakarta: BPFE.

Syafiie, Inu Kencana. 2007. Pengantar Ilmu Pemerintahan. Bandung: Refika Aditama. 2013. Ilmu Pemerintahan. Jakarta: Bumi Aksara.

Usman, Husaini. 2001. Metode Penelitian Sosial. Bandung: Bumi Aksara

Dokumen:

Republik Indonesia. 2013. Undang-undang No 13 Tahun 2011 tentang Penanganan Fakir Miskin. Jakarta: Legalitas.

Republik Indonesia. 2014. Undang-undang No.23 Tahun 2014 tentang Pemerintah Daerah. Jakarta: Legalitas.

Republik Indonesia. 2010. Peraturan Presiden No 15 Tahun 2010 tentang Percepatan Penanggulangan Kemiskinan. Jakarta: Legalitas.

Republik Indonesia. 2015. Peraturan Presiden No 7 Tahun 2015 tentang Organisasi Kementerian Negara. Jakarta: Legalitas.

Republik Indonesia. 2015. Peraturan Presiden No 46 Tahun 2015tentang Kementerian Sosial. Jakarta: Legalitas.

Republik Indonesia. 2012. Peraturan Pemerintah No 39 Tahun 2012 tentang Penyelenggaraan Kesejahteraan Sosial. Jakarta: Legalitas. 
Republik Indonesia. 2015. Peraturan Menteri Keuangan RI Nomor 254/PMK.05/2015 tentang Belanja Bantuan Sosial pada Kementerian Negara/Lembaga. Jakarta: Legalitas

Republik Indonesia. 2008. Pedoman Umum Program Keluarga Harapan. Jakarta: Kementerian Sosial

Republik Indonesia. 2016. Pedoman Umum Program Keluarga Harapan. Jakarta. Kemeterian Sosial. 